\title{
Lost in transition? Substance abuse and risk of labour market exclusion from youth to adulthood
}

\author{
Torild Hammer and Christer Hyggen \\ Norwegian Social Research (NOVA), P.O. Box 3223 Elisenberg, N-0208 Oslo, Norway \\ E-mail: torild.hammer@nova.no
}

\begin{abstract}
Despite low levels of youth unemployment in Norway, concerns have been raised about the high numbers of youth in inactivity, receiving health related social security benefits. It is argued that parts of the system of social security may work as welfare traps. OECD recommends welfare policies with the overall aim of fostering youth employability, not benefit dependency. In this article we use a unique combination of register data and survey data from the panel survey "work, lifestyle and health". This survey follows a representative sample of the cohorts born between 1965 and 1968 from 1985 through follow-ups in 1987, 1989, 1993 and 2003. This allows us to follow individual life trajectories from ages 17-20 to 35-39. The aim of the article is first to study the impact of substance abuse upon risk of receiving social assistance, since previous research has found that receiving social assistance increases the probability of labour market exclusion in adulthood. Second, we analyse the impact of receiving social assistance, to have mental health problems and substance abuse in youth and consequences for labour market integration in adulthood. Analyses reveal that neither cannabis use nor alcohol consumption in youth have a direct effect on the risk of labour market exclusion in adulthood. However, cannabis use increases the probability of receiving social assistance, which in turn increases risk of labour market exclusion in adulthood. Mental health problems in youth increase risk for later labour market exclusion, but these effects are mediated through factors like problem behaviour related to alcohol abuse and the use of illegal drugs other than cannabis. Receiving social assistance in youth has long time effects on the risk of labour market exclusion, especially for individuals from the lower socioeconomic groups.
\end{abstract}

\section{INTRODUCTION}

A recently published OECD report evaluates the school to work transition in Norway (OECD, 2008). Here, it is stated that youth unemployment in Norway is low compared to the OECD average; however, the OECD evaluation team is particularly concerned about the high share of youth receiving sickness- or disabilityrelated benefits and/or being "inactive" (not in school and not registered in the labour force). It has been pointed out that although those leaving school have no right to unemployment benefits, other parts of the social protection system can operate as welfare traps. The report presents a list of recommendations with the overall aim that unemployment and welfare policies should foster youth employability, not benefit dependency. One recommendation of special interest for our research is to "better identify individuals under the age of 30 as the at-risk group that should be targeted and given priority among the Norwegian labour and welfare organisation (NAV) clients" (p 21).

In spite of low unemployment in Norway in 2009, 80,000 young people below the age of 30 were out of school and the labour market, and were receiving disability benefits, rehabilitation money, sickness benefits, and social assistance or unemployment benefits. Moreover, there were 12,000 young people under 30 who received disability benefits, which is a sharp increase since 1990, especially among young people with psychiatric diseases (Brage and Thune, 2008).
The highest increase was among young people with diagnoses of anxiety and depression. Nevertheless, we know that drug and alcohol abuse in itself is not usually a diagnosis that qualifies a person for disability benefits, only a diagnosis for long-term health problems as a consequence of such abuse. An interesting question is therefore to what extent combinations of substance abuse and mental health problems, as well as labour market exclusion, may explain increasing disability rates and inactivity among young people (Hammer, 2009a). There has been an increase in the use of drug and alcohol consumption in the general population over the last few years, particularly among young people. In the age group from 19 to 20 years, this consumption has increased from 3.8 litres of pure alcohol to 7.6 litres from 1993 to 2007 (Sirus statistics, 2008). Previous research has showed that when alcohol consumption doubles, the proportion of young people with abuse problems will increase fourfold (Skog, 1980). The injection of hard drugs has increased from 0.3 to 0.6 percent in the same time period (Sirus statistics, 2008). There has also been an increase in drug use in the general population under 30, and an increase of alcohol in the older population.

It has been calculated that the average consumption of alcohol in the general population is approximately 8 litres of pure alcohol per year (Sirus statistics, 2008). However, the 10 percent of the population with the highest consumption drink more than 50 percent of the total alcohol consumption, an average of more than 40 
litres of pure alcohol per year. This group could be characterised as persons with a drinking problem.

Within the population, this group has the highest risk of unemployment, alcohol-related sickness absence, problems in the work place and work accidents, especially among young single men (Grimsmo and Rossow, 1997; Hammer, 1997). According to Norström and Moan (2009), an increase in alcohol consumption of one litre of pure alcohol on average in the general population leads to an increase of 13 percent sickness absence among men and 7 percent among women. From a life course perspective, this may lead to an increased risk of unemployment and exclusion from the labour market. Additionally, rising unemployment in today's Norwegian labour market implies higher unemployment rates and rates of inactivity in such groups and an increased use of social assistance and other types of social security benefits.

\section{A new adulthood}

In today's world, young people stay in education for a greater proportion of their lives, postpone marriage and parenthood and enter the labour market at a later stage compared to previous generations. This extended youth transition into adulthood is sometimes referred to as "new adulthood", a type of extension of youth without serious responsibilities towards family and work, and a prolonged period of youth with few obligations. Hayford and Furstenberg (2008) conclude that although the achievement of adult roles is being pushed to an older age, this stretching of the transition to adulthood is not reflected in observed patterns of substance abuse. Other studies have looked at different groups of adolescents and change and continuity of consumption patterns in young adulthood, and found a moderately strong continuity (Osterle et al., 2008). A study by Schulenberg et al. (2005) on the continuation and cessation of cannabis use into adulthood found that marriage and parenthood reduced the probability for the continuation of use, while unemployment increased the likelihood of belonging to the group of chronic and increased users. Still, no other Norwegian study has looked at such transition patterns. Moreover, high unemployment rates and welfare dependency may also prolong the period of this new adulthood. Therefore, an important question is to what extent these young adults are trapped in transition?

\section{Youth unemployment and risk of social assistance}

Because they lack work experience, many young unemployed people are not entitled to unemployment benefits and are therefore dependent on their families for support and/or social assistance. In Norway, social assistance represents a basic security net for those who are not entitled to unemployment benefits or other social security benefits. To receive social assistance is still heavily stigmatised in Norway; one must undergo a means test and recipients usually consider it to be the financial solution of last resort (Halvorsen, 1996).
From earlier research, we know that young social assistance recipients often have less education, more health problems, more financial problems and a longer duration of unemployment than other unemployed youth (Hammer, 2001; Hyggen, 2010), as well as a higher consumption of drugs and alcohol than other young people. Previous research (Hammer and Vaglum, 1990) has found that among young unemployed people the probability of receiving social assistance increased four times among those who had used cannabis before the age of 17 . Nonetheless, the consumption of alcohol had no significant effect, although alcohol consumption was three times as high among those who experimented with cannabis in comparison to their peers (Hammer, 1992). Cannabis users seemed to experience more mental health problems related to unemployment than other young people, independent of their current drug use. Those who were unemployed had a higher probability of continuous drug use in young adulthood, and unemployment was also related to increasing drug use among those who only experimented with drugs. A combination of unemployment and drug use is the most probable cause leading to an increased marginalisation of susceptible groups (Hammer, 1992). Since only a small proportion of the cannabis users become involved in the use of other illegal drugs, alcohol consumption may represent a greater problem than drug use from a perspective of prevention. This may be of special importance with regard to female cannabis users, who had a masculine drinking pattern and higher probability of increasing alcohol use in relation to continuous drug use. In most studies, unemployment is associated with a reduced aggregated level of alcohol consumption primarily because of a reduced income. However, some studies indicate that certain groups of the unemployed seem to increase their drinking. In a five-year follow-up in Norway, Claussen (1999) discovered a higher prevalence of harmful drinking among the unemployed compared with those who were employed. Furthermore, several studies have shown that drinking problems and drug use increase the probability of unemployment (Johansson et al., 2007), increased sickness absence (Norstrom, 2006) and disability (Upmark et al., 1999). In addition, in a longitudinal study, Upmark et al. (1999) found that the effects of alcohol on high levels of sickness absence, and the occurrence of disability pensions five to seven years after baseline, suggested that there is also an effect on working incapacity independent of previous health status, smoking and socioeconomic group.

Youth at risk may have special problems in adapting to labour markets that change as a function of an increased demand for flexible, mobile and well educated labour. Low skilled jobs which may facilitate the entry of disabled people or those with lower competence levels into the labour market may tend to vanish. (Høgelund and Greve Pedersen, 2001). According to the OECD, less than 5 percent of jobs in the Norwe- 
gian labour market are unskilled (OECD, 2008). Unemployed youth, particularly those who become dependent on social assistance, are known to have less education than their contemporaries (Hammer, 2001). Their lesser qualifications suggest that they will be forced to accept jobs requiring low skills and jobs in the periphery of the labour market.

Unemployed youth, and social assistance recipients in particular, often have working class backgrounds and low levels of education. They may have to accept jobs in the periphery of the labour market that require a low level of skills and often on fixed-term contracts. Previous research has found that "ordinary" even longterm unemployed youth, turn into productive workers with good and stable jobs with a high degree of work satisfaction in adulthood. However, those who received social assistance when they were young did not have such a favourable career. In adulthood, they still had a marginalised position on the labour market, characterised by fewer possibilities for internal training, temporary work contracts and few prospects for future careers in the firm (Hammer 2007, Hammer and Hyggen, 2006). Moreover, social assistance recipients have a high risk of later exclusion from the labour market. A previous study showed that among those who received social assistance as young between 20 and 24 percent lived by public support in adulthood (Hammer, 2009b). On this background we here want to answer the following questions:

- How does use of drugs and alcohol influence risk of social assistance in youth?

- To what degree does the combination of social assistance, mental health problems and substance abuse lead to risk of exclusion from the labour market in adulthood? Are there gender differences?

\section{METHOD AND DATA}

The research questions will be investigated by using a unique combination of register data and survey data from the "Work, Lifestyle and Health" survey, which is a longitudinal panel survey that has followed a sample of nearly 2,000 individuals who were representative of the Norwegian cohorts born between 1965 and 1968. The survey was introduced in 1985, with followups in 1987, 1989, 1993 and 2003.

The time window for the survey spans the period from 1985 to 2003, thus allowing us to view individual life trajectories from the ages of 17-20 to 35-39. The panel was stratified based upon the individual's primary occupation in 1985: young people who were still completing their education had the lowest probability of being included in the sample $(0.25, \mathrm{~N}=801)$, whereas those who were employed had a higher probability $(0.70, \mathrm{~N}=800)$, and those who were neither working nor completing their education had the highest probability of inclusion $(1.00, \mathrm{~N}=394)$. The stratification variable has been controlled for in all analyses.

Statistics Norway has been responsible for the data collection. The response rates throughout the study have been stunningly high: 85 percent of the sample participated in the survey in 1985,80 percent in 1987 , 74 percent in 1989, 73 percent in 1993 and 70 percent in 2003. In other words the cumulative response rate in 2003 is $\left(0.85^{*} 0.70\right) 60$ percent.

The register data information was collected from the FD-trygd register (register of all social benefits received) at Statistics Norway and from registers of personal income and education, and these data were matched with individual responses for the entire period. The official records allowed us to track the individual careers in detail and to trace other forms of social security such as unemployment, sickness and disability benefits, as well as the frequency, duration and amount of transitional benefits. In addition, we had access to individual paths of education and employment careers. When connected to data from the panel survey, this unique source of information provides us with an opportunity to understand the different transitions from youth to adulthood.

\section{MEASUREMENTS AND STATISTICAL METHODS}

Exclusion from the labour market (the dependent variable) is defined by living on various sources of public income such as transitional benefits, rehabilitation benefits, social assistance, unemployment benefits, longterm sick benefits or disability by register data. This is the only measure in the analysis were we use register data.

- Alcohol consumption was measured at every follow-up as the annual cl consumption of pure alcohol based on information about the frequency of consumption over the last four weeks, how much was consumed in the last drinking incidence, the frequency of drinking during the last year (Brun Guldbrandsen (1976). For a discussion of validity and reliability of this measurement see Horverak and Bye (2007).

- Cannabis use was measured by use the last year (yes/no).

- Use of other illegal drugs at any time.

- Alcohol problems were measured by five questions (Yes/No): Have you ever run into any of the following problems because of drinking too much over the past 12 months? (Yes/ No):

Quarrelling or unfriendliness

Made enemies or had quarrels/fighting?

Had problems in school or work?

Had any accidents or injuries?

Been taken by the police?

- Alcohol problems were also measured by eight questions according to DSM 111. All respondents were asked in 1993 whether they ever had experienced the following problems during the last six months (Yes/No). On the basis of these questions, an additive index for alcohol problems was constructed. 
Table 1. Description of variables in the equations, unweighted numbers.

\begin{tabular}{lccccc}
\hline & $\mathrm{N}$ & Minimum & Maximum & Mean & Std. deviation \\
\hline Age 1985, pr. 31.12 & 1997 & 17 & 20 & 18.69 & 1.118 \\
Single parent 1987 & 1173 & 0 & 1 & $11 \%$ & \\
Have children 1987 & 1169 & 0 & 1 & $19 \%$ & \\
Alcohol problems 1993 & 907 & 0 & 11 & 0.73 & 1.325 \\
Mental health, 1987 & 1173 & 1.00 & 3.70 & 1.32 & 0.362 \\
Mental health, 1993 & 994 & 1.00 & 3.80 & 1.32 & 0.410 \\
Main occupation, 1985 & 1173 & 1 & 3 & 1.45 & 0.658 \\
Sex Men=1 & 1002 & 0 & 1 & $46 \%$ & \\
Received social assistance 1987 to 1993 & 1173 & 0 & 1 & $15 \%$ & \\
School dropout, 1987 & 1169 & 0 & 1 & $8 \%$ & \\
Parental divorce & 1006 & 0 & 1 & $16 \%$ & \\
Evaluation of own health 2003 & 1168 & 1 & 5 & 1.95 & 0.821 \\
Alcohol consumption, 1987 & 1173 & 0 & 7892 & 400 & 873 \\
Socioeconomic status & 1038 & 1 & 4 & 2.39 & 0.99 \\
Cannabis use, 1987 & 1173 & 0 & 1 & $9 \%$ & \\
Use of other illegal drugs 1993 & 1173 & 0 & 1 & $6 \%$ & \\
Live by public support in 2003 (dependent variable) & 1167 & 0 & 1 & $19 \%$ & \\
\hline
\end{tabular}

Problem to stop drinking?

Worried about your own drinking?

Did not manage to get up in the morning because of drinking?

Did not manage to go to work because of drinking?

Drinking and driving?

Criticised by others close to you because of your drinking?

People close to you worried about your drinking?

- Mental health was measured by 10 items on the Hopkins Symptoms Checklist (HSCL-10) (Derogatis et al, 1974) for anxiety and depression which had been selected by the factor analysis of a health survey of the same age group as per the 1985 CBS survey. We constructed an additive index.

- Physical health. An evaluation of one's own health, from very satisfied to least satisfied.

- Social class was measured according to the father's occupation and education and respondents were categorized into 4 socioeconomic groups (Skrede's index for classification of social groups; Skrede, 1971). Where information concerning father's occupation was missing, the mother's education was used instead.

- Conditions of upbringing were measured according to being raised with both parents, in a one-parent family, or with others, before 15 years of age.

- Social assistance was operationalised as financial support from the system of social assistance.

- Occupation in 1985 (stratification variable) was defined by whether they were in school, working or unemployed/outside the labour market.

- Education was measured by number of years after compulsory school.

- School dropout was measured in 1987 as dropping out of school without an examination.

\section{Statistical analysis}

Statistical analysis was carried out using logistic regression with the SPSS statistical package. The stratification variable is controlled for in all analysis. There were skewed attrition from 1985 to 1987 , and 1989 among those who were unemployed in 1985 . The unemployed in 1985 had lesser probability to answer the questionnaire the following years. Moreover, there was clearly skewed attrition among those who reported social assistance in 1987 in 2003. The response rate in 2003 was $70 \%$, however among social assistance clients the response rate was $50 \%$.This is a problem as regards generalization of the results. On the other hand, this was somewhat compensated for by the stratification variable where groups with a high probability of attrition (the young unemployed in 1985) were oversampled. Most of the social assistance clients in 1987 were unemployed in 1985.

Table 1 gives a description of all variables included for further analysis. As shown in Table 1, 19 percent lived by some type of public support in adulthood using unweighted estimates.

\section{RESULTS}

As discussed in the introduction, to receive social assistance when young seems to be an identified risk factor for later marginalisation in the labour market. Consequently, we will first look at the selection to social assistance as a young person.

Table 2 reveals a strong effect from mental health problems, to be a single parent, to use cannabis and to be previously unemployed. Young unemployed parents with low education, especially single mothers, often have children very early and will be dependent upon social assistance and other benefits at an early age. They often also have parents with a low socioeco- 
Table 3. Predictors of living by public support in 2003 ( $N=963)$; Unweighted estimates.

\begin{tabular}{lcccccc}
\hline & \multicolumn{3}{c}{ Model 1 } & \multicolumn{3}{c}{ Model 2 } \\
\cline { 2 - 7 } & B & Sig. & Exp(B) & B & Sig. & Exp(B) \\
\hline Received social assistance, 1987-1993 & 0.628 & $*$ & 1.873 & 0.570 & $*$ & 1.769 \\
Mental health, 1987 & 0.341 & $*$ & 1.407 & 0.287 & & 1.332 \\
Men=1 & -0.48 & $*$ & 0.619 & -0.537 & $*$ & 0.585 \\
Socioeconomic group 2 & -0.758 & & 0.469 & -0.768 & $*$ & 0.464 \\
Socioeconomic group 3 & -0.511 & $*$ & 0.600 & -0.552 & $*$ & 0.575 \\
Socioeconomic group 4a & -1.051 & $*$ & 0.350 & -1.050 & $*$ & 0.350 \\
SES 4* received social assistance & 1.336 & $*$ & 3.804 & 1.303 & $* *$ & 3.679 \\
Cannabis use, 1987 & 0.024 & & 1.024 & -0.146 & & 0.864 \\
Alcohol consumption, 1987 & 0 & & 1 & 0 & & 1.00 \\
School dropout, 1987 & 0.201 & & 1.024 & 0.092 & & 1.096 \\
Parental divorce before 15 years old & 0.287 & & 1.332 & 0.294 & & 1.342 \\
Other illegal drugs 1993 & & & & 0.838 & $* *$ & 2.311 \\
Employed, 1985 & & & & 0.139 & & 1.149 \\
Unemployed, 1985b & & & & 0.442 & & 1.556 \\
Alcohol problems 1993 & & & & 0.014 & & 1.014 \\
Constant & $-1,739$ & & 0.176 & -1.713 & & 0.179 \\
Cox and Snell R Square & & 0.048 & & & 0.055 & \\
\hline
\end{tabular}

Reference group $\mathrm{a}=$ Socioeconomic group 1 , Reference group $\mathrm{b}=$ in education 1985

${ }^{*} \mathrm{p}<0.05, * * \mathrm{P}<=.01$

Table 2. Selection to social assistance in youth (1987 to 1993) ( $\mathrm{N}=980)$.

\begin{tabular}{lcccc}
\hline & B & S.E. & Sig. & Exp(B) \\
\hline Single parent=1 & .802 & .293 & .006 & 2.230 \\
Have children & .607 & .306 & .047 & 1.835 \\
Parental divorce & .585 & .261 & .025 & 1.795 \\
Mental health, 1987 & .131 & .026 & .000 & 1.140 \\
School dropout, 1987 & .539 & .333 & .106 & 1.714 \\
Alcohol consumption, 1987 & .000 & .000 & .766 & 1.000 \\
Use of cannabis, 1987 & .619 & .312 & .047 & 1.856 \\
Socioeconomic group 2 & .237 & .302 & .432 & 1.268 \\
Socioeconomic group 3 & .145 & .275 & .599 & 1.156 \\
Socioeconomic group 4a & .571 & .351 & .104 & 1.771 \\
Employed, 1985 & .152 & .261 & .561 & 1.164 \\
Unemployed, 1985b & .901 & .340 & .008 & 2.462 \\
Constant & -4.385 & .439 & .000 & .012 \\
\hline
\end{tabular}

* Reference groups $=\mathrm{b}$ in education; a Socioeconomic group 1

nomic background. However, this is not the case for cannabis users. Cannabis use in youth clearly also increased the probability of receiving social assistance.

If we do not include the variable of mental health measured in 1987 in the analyses, both social background and the school dropout rate before 1987 are highly significant, implying that those with parents with a low socioeconomic status have a higher probability of receiving social assistance.

The next step is to look at how receiving social assistance when young influences the risk of labour market exclusion in adulthood.

Table 3 gives a multivariate analysis in order to predict exclusion from the labour market in adulthood based on the situation in youth. We include relevant variables such as parents divorce and socioeconomic background, unemployment, school dropout, mental health and use of drugs and alcohol.

Table 3 shows that to have previously received social assistance increases the risk of exclusion in adulthood, particularly among those who received social assistance when young with parents who had a low socioeconomic status (unskilled workers), which is demonstrated by a significant interaction effect. The table also shows that women have a higher risk of living by public support in adulthood than men. Further analysis shows that many of those excluded from the labour market receive transitional benefits if single mothers. In total, 22 percent of those excluded from the labour market were single parents versus 7 percent of those integrated into the labour market $(p<0.001)$. Moreover, mental health problems when young increase the risk of later exclusion from the labour market. However, neither a high alcohol consumption nor cannabis use, unemployment or school dropout in youth have such consequences. These factors primarily increase the risk of receiving social assistance (Table 1 ), that may in turn increase later labour market exclusion.

Cannabis use and alcohol consumption among young people have a high prevalence in the youth population. Yet, dropping out of school, cannabis use and youth unemployment increase the probability of receiving social assistance when young. The next question is whether alcohol problems and the use of other illegal drugs than cannabis as an indication of drug problems have any effects. Model 2 shows that to receive social assistance when young still has an impact, but using other illegal drugs than cannabis has an effect. Alcohol problems did not have any significant effect, moreover previous measures of mental health 
Table 4. Predictors of living by public support in 2003 ( $N=960$ ).

\begin{tabular}{lccc}
\hline & \multicolumn{3}{c}{ Model 3 } \\
\cline { 2 - 5 } & B & Sig. & Exp(B) \\
\hline Received social assistance, 1987-1993 & 0.586 & $*$ & 1.796 \\
Mental health, 1993 & 0.730 & $*$ & 2.074 \\
Men=1 & -0.511 & $*$ & 0.600 \\
Socioeconomic group 2 & 0.568 & $*$ & 0.566 \\
Socioeconomic group 3 & -0.285 & & 0.752 \\
Socioeconomic group 4a & -0.536 & & 0.585 \\
SES 4* received social assistance & 1.118 & $* *$ & 3.058 \\
Other illegal drugs=1 1993 & 0.678 & $*$ & 1.969 \\
Alcohol problems, 1993 & 0.017 & & 1.018 \\
Evaluation of health, 2003 & 0.719 & $*$ & 2.053 \\
Constant & -2.279 & $*$ & .010 \\
-2 Log likelihood 752,50, Cox \& Snell R2 & \multicolumn{3}{c}{0.091} \\
\hline
\end{tabular}

Reference group a=Socioeconomic group 1

$* \mathrm{p}<0.05 * * \mathrm{p}<0.01$

are not significant as long as use of other illegal drugs and alcohol problems are controlled for. Furthermore, further analysis (not showed in the table) documented that other measures of physical health in 1987 or whether they were treated for medical problems when young were not significant either.

However, if we include measures of mental health in 1993 and their own evaluation of their health last year, the picture is different.

The stratification variable was not significant and is not included in the analysis, thereby implying that unemployment when young had no effect when controlling for the selection to social assistance. The table reveals that both an evaluation of one's own health the last year and mental health measured 10 years previously, have a strong and significant impact. Interestingly, alcohol problems are not significant. However, if we control for alcohol problems the last year, this measure has a clear effect, but not after controlling for evaluation of own health the last year. However, it is possible that such health problems are a consequence of previous alcohol problems or the other way around. The use of other illegal drugs than cannabis still has a significant effect in itself. Additionally, the significance of receiving social assistance among young people with parents from a low socioeconomic background is still significant. This could be a selection effect or possibly an effect of a very low competence level. Surprisingly, the total numbers of years of education (not showed in the table) had no significant impact. An interesting question is whether the combination of substance abuse and mental health problems could explain exclusion from the labour market. However, we have tested for different interaction effects between mental health, illegal drug use and alcohol problems and neither showed any effects.

\section{DisCUSSION}

The discussion about why so many young people have become inactive (not in work or education) in Norway, has led to various hypotheses about the reason for such a development.

\section{School drop out}

Many have argued that the high dropout rate in upper secondary school is one reason, as one-third drop out from upper secondary education. However, we found that neither dropping out of school nor the number of years in education had any direct impact. Nevertheless, being a school dropout is an important criterion for receiving social assistance and receiving social assistance when young increases the probability of labour market exclusion in adulthood. These results are in accordance with a recent research report that followed all individuals born in the period from 1977 to 1987 by register data. The problem of being a school dropout has increased. While 29 percent of the 1998 cohort that started school this year did not complete upper secondary school, the number was 33.5 percent of the 2003 cohort. They found that the probability of receiving disability benefits later was 2-4 percent in 2007 among those who did not complete school, and the probability of being unemployed was 3-5 times greater for school dropouts. More interestingly, the probability of receiving social assistance was 9.5 times greater for those who dropped out compared with those who completed school within five yars (Falch and Nyhus, 2009).

\section{Selection to social assistance}

We discovered through our analysis that receiving social assistance when young had some long-term effect, especially among young people who have parents with a low socioeconomic status. The results remain significant also after controlling for the use of illegal drugs and alcohol. There seems to be a selection effect at work. Young people usually become dependent on social assistance because they lack work experience and are not entitled to unemployment benefits. Some young people also receive such a low level of unemployment benefits, or are single mothers receiving transitional benefits, that they can claim some additional social assistance. The selection effect implies that they do not receive private support by parents or by a husband. Young people in the transition from school to work are often not entitled to benefits. Usually, they have their parents supporting them, although this of course can be difficult for parents with a low socioeconomic status/low income.

From earlier research, we know that young social assistance recipients often have less education, more health problems, more financial problems and a longer duration of unemployment than other unemployed youth (Hammer, 2001; Hyggen, 2010), as well as a higher consumption of drugs and alcohol than other young people. Previous research (Hammer and Vaglum, 1990) has found that among young unemployed people, the probability of receiving social assistance increased four times among those who had used cannabis before the age of 17 . However, the consumption of alcohol had no significant effect. On the 
other hand, alcohol consumption was three times as high in those who experimented with cannabis compared to other young people (Hammer, 1992).

The results here demonstrated that neither cannabis use nor alcohol consumption in youth had any direct effect on the risk of exclusion from the labour market in adulthood. This is in accordance with previous findings from the work lifestyle and health survey (Hyggen, 2009). Nonetheless, cannabis use, being a school dropout and unemployment characterise those who receive social assistance in youth.

\section{Unemployed young mothers}

More females than males were excluded from the labour market and half of them were single mothers living on transitional benefits, which we did not expect. It looks as if having a child early in the female transitional period seems to act as a trap, although teenage pregnancy is not a great problem in Norway. Therefore, even if the average age for having children has increased by several years, the last generation of young women with a low education have children at the same age as their mothers (Ellingsæter et al., 1993). Moreover, previous research has discovered that having a child can act as a way out of unemployment for young women with a low education, giving them the role of mother and a shortcut to adult status (Wallace, 1986; Hammer, 1992). Be that as it may, the results here show that receiving transitional benefits as a single mother and additional social assistance is not a good solution. They have often low education and little work experience. and further career may imply exclusion from the labour market in adulthood. Thus, they are trapped in transition.

\section{Risk of social exclusion}

However, to be excluded from the labour market does not necessarily imply social exclusion as discussed in the introduction. Looking at it from another viewpoint, it seems that dropping out of school, early unemployment, cannabis use and mental health problems in youth increase the probability of receiving social assistance when young. The results also clearly show that those who have parents with a low socioeconomic status have a high risk of labour market exclusion in adulthood. In addition, an increasing alcohol consumption and use of other illegal drugs definitely increases the risk of later labour market problems in adulthood, probably leading to health problems and the risk of both labour market exclusion and social exclu- sion. In contrast, mental health problems when young also had an effect in the multivariate analysis, though not if we controlled for alcohol problems and the use of other illegal drugs than cannabis. The probability of exclusion was two times higher among those who had used other illegal drugs than cannabis. Unfortunately, we do not have any information about delinquency. However, we know from previous research that the use of illegal drugs is often associated with criminality and periods in prison, thus probably leading to further exclusion from the labour market. Reporting alcohol problems also had an impact on risk of exclusion. Even so, this effect is significantly reduced when controlling for self reported health problems. In any case, it is difficult to sort out the effects since health problems can also be a consequence of illegal drug use and heavy alcohol consumption.

In other words, the results here may imply that the increase of disability rates in young people could be caused by a combination of mental health problems and abuse problems. Previous research has shown that young people receiving a disability pension have low education and little work experience. They feel isolated, lonely and socially excluded from society (Blekesaune, 2005). Paugam (1996) claims that extreme forms of marginalisation occur when unemployment is coupled with a disintegration of the social networks that bind an individual to the community. In his view, social exclusion represents the end of a process of cumulative disadvantage, with less stable family relationships possibly creating isolation and vulnerability.

This development calls for preventive measures directed towards school drop outs, cannabis use and mental health problems in youth that increases the risk of receiving social assistance. School drop out is very high in Norway (about 30\%) and reach $40 \%$ of the pupils in vocational education (Hernes, 2010). What could be done is first to ensure that all young people receive an offer of apprenticeship training. Second to develop measures in order to use teachers to help pupils with learning difficulties in the school on a private basis supported as learning programme. Another important measure is to strengthen the qualification programme where young unemployed social assistance recipients are a target group. Moreover, an initiative should be taken as regards alcohol and drug abuse among young people. Disability pension at a young age is a problem both for those whom it concerns as well as society.

\section{REFERENCES}

Blekesaune M (2005). Unge uførepensjonister. Hvem er de, og hvor kommer de fra? (Young people with disability benefits. Who are they, and where do they come from?) NOVA rapport 8/05, Oslo: NOVA.

Brage S, Thune O (2008). Medisinske årsaker til uføreytelser blant unge 1977-2006. Arbeid og Velferd, Oslo: Arbeids- og velferdsdirektoratet.

Bruun Guldbrandsen (1976). Upublisert manuskript. Oslo, SIFA, Statens Institutt for alkoholforskning.

Claussen B (1999). Alcohol disorders and re-employment in a 5-year follow-up of long-term unemployed. Addiction 94: 133138. 
Derogati LR, Lipman RS, Uhlenhut EH, Covi L (1974). The Hopkins Symptom Checklist: A self-report symptom inventory. Behav Sci 19: 1-15.

Ellingsæter AL, Noack T, Rønsen M (1993). Utdanning, arbeid og inntekt: Hvor likestilte har kvinner og menn blitt? (Education, work and income: How equal have women and men become?) Samfunnsspeilet 1: 2-9.

Falch T, Nyhus OH (2009). Frafall i videregående opplæring og arbeidsmarkedstilknytning for unge voksne. Trondheim, Senter for økonomisk forskning. SØF rapport nr 07/09.

Friedman AS, Terras A, Zhu W (2004). Early adolescence substance use/abuse as predictor to employment in adulthood: Gender differences. J Child Adolesc Subst Abuse 13: 49-60.

Johansson E, Alho H, Kiiskinen U, Poikolainen K (2007). The association of alcohol dependency with employment probability: Evidence from the population survey 'Health 2000 in Finland'. Health Econ 16: 739-754.

Grimsmo A, Rossow I (1997). Alkohol og sykefravær. Oslo: Statens institutt for alcohol-og narkotikaforskning. Rapport 97:3.

Hernes G (2010). Gull av gråstein. Tiltak for å redusere frafall i videregående opplæring. Oslo: FAFO-rapport 2010:3.

Halvorsen K (1996). Utsatt posisjon i arbeidsmarkedet - en hovedvei til bistandsavhengighet (Exclusion from the labour market, the main track to benefit dependency?). In: Halvorsen, K (ed). Mestring av marginalitet (Coping with marginality). Oslo, Cappelen Akademisk Forlag.

Hammer T, Vaglum P (1990). Forbruk av rusmidler og rekruttering til sosialhjelp blant unge arbeidsløse i Norge (Substance abuse and selection to social assistance among young unemployed people in Norway). Alkoholpolitik, Nordisk tidsskrift for alkoholforskning 7: 75-84.

Hammer T (1992). Unemployment and use of drug and alcohol among young people: a longitudinal study in the general population. Br J Addict 87: 1571-1581.

Hammer T (1992). Unemployment and marginalization among young-people. Tidsskr Samfunnsforskn 33 (6): 513-528.

Hammer T (2000). Mental health and social exclusion among unemployed youth in Scandinavia. A comparative study. Int $J$ Soc Welfare 9: 53-63.

Hammer T (2001). Arbeidsløse sosialklienter i de nordiske land (Unemployed social assistance clients in the Nordic countries). Tidsskrift for velferdsforskning 4: 120-134.

Hammer T (1999). Sykefravær og rusmiddelbruk blant unge i arbeid. Oslo: NOVA rapport 6/99.

Hammer T, Hyggen C (2006). Stengte dører? Unge sosialklienters arbeidstilpasning i voksen alder. I: Hammer T, Øverbye E (red): Inkluderende arbeidsliv. Erfaringer og strategier. Oslo:Gyldenda1/Akademiske: S32-50.

Hammer T (2007). Labour market integration of unemployed youth from a life course perspective. The case of Norway. Int $J$ Soc Welfare 16: 249-257.

Hammer T (2009a). Hvorfor blir flere unge uførepensjonister? Tidsskrift for velferdsforskning 12: 55-61.

Hammer T (2009b). Unge sosialklienter fra ungdom til voksen alder. NOVA rapport nr. 11/09.

Hayford SR, Furstenberg FF (2008). Delayed adulthood, delayed desistance? Trends in age distribution of problem behaviours. J Res Adolesc 18: 285-304.

Heckman JJ (1981). Heterogeneity and state dependence. In: Rosen S (ed): Studies in Labor Markets. National Bureau of Economic Research no. 31. Chicago and London: The University of Chicago Press.

Horverak Ø, Bye EK (2007). Det norske drikkemønstret, Rapport nr 2/2007.

Hyggen C (2010). Livsløp i velferdsstaten. Sosialhjelp og risiko. Doktoravhandling. NOVA Rapport 6/2010. Oslo: NOVA.

Hyggen C (2009). Unge arbeidsuføre - livsløp og risiko. Tidsskrift for velferdsforskning 12: 80-93.

Høgelund J, Greve Pedersen J (2001). The employment situation of disabled people in Denmark. The open labour market, Working paper 10:2001. Copenhagen: The Danish National Institute of Social Research

Maggs JL, Schulenberg JE (2004/2005). Trajectories of alcohol use during the transition to adulthood. Alcohol Res Health 28: 195-201.

Norström T, Moan IS (2009). Per capita alcohol consumption and sickness absence in Norway. Eur J Public Health 19: $383-$ 388.

Oesterle S, Hill KG, Hawkins JD, Abbott RD (2008). Positive functioning and alcohol use disorders from adolescence to young adulthood. $J$ Stud Alcohol Drugs 69: 100-110.

OECD (2008) Jobs for youth. Norway. Paris: OECD.

Paugam S (1996). Poverty and social disqualification: A comparative analysis of cumulative social advantage in Europe. $J$ Eur Soc Policy 4: 287-303.

Schulenberg JE, Merline AC, Johnston LD, O’Malley PM, Bachman JG, Laetz VB (2005). Trajectories of marijuana use during the transition to adulthood: The big picture based on national panel data. J Drug Issues 35: 255-279.

Skog OJ (1980). Is alcohol consumption lognormally distributed? Br J Addiction 75: 169-73.

Sirus Statistics (2008). www.sirus.no.

Skrede K (1971). Sosioøkonomisk klassifisering av yrker I Norge. INAS rapport report no 71-1.

Upmark M, Møller J, Romelsjø A (1999). Longitudinal, population based study of self reported alcohol habits, high level of sickness absence and disability pensions. J Epidemiol Community Health 53: 223-229.

Wallace C (1986). From girls and boys to women and men: The social reproduction of gender roles in transition from school to (un) employment. In: Walker S, Barton L (eds). Youth unemployment and schooling. England: Open University Press: $92-$ 118 . 